\title{
IMPLEMENTASI PENILAIAN FORMATIF DALAM PEMBELAJARAN BAHASA INGGRIS TATAP MUKA TERBATAS UNTUK MENINGKATKAN MOTIVASI BELAJAR SISWA
}

\author{
ASEP DUDI KURNIA \\ MTs. Babakan \\ e-mail: asdudmail@gmail.com
}

\begin{abstract}
ABSTRAK
Artikel ini membahas tentang implementasi penilaian formatif yang dihubungkan dengan motivasi belajar siswa, khususnya pelajaran bahasa Inggris dalam kondisi pembelajaran tatap muka terbatas. Pembelajaran tatap muka terbatas umumnya dilakukan secara singkat sehingga guru terkadang merasa kesulitan untuk menerapkan penilaian formatif. Oleh sebab itu, penelitian ini mencoba menggali strategi penilaian formatif yang mungkin dilakukan dalam pembelajaran bahasa Inggris, serta sejauhmana siswa termotivasi dengan implementasi tersebut. Penelitian dilakukan secara kualitatif dengan desain studi kasus pada sebuah Madrasah Tsanawiyah di Ciamis, Jawa Barat. Observasi dan angket digunakan untuk memperoleh data dari seorang guru dan tiga orang siswa dengan prestasi berbeda. Data yang terkumpul lalu dianalisis secara kualitatif. Berdasarkan data observasi dan angket, terlihat bahwa meskipun dalam kondisi pembelajaran tatap muka terbatas, penilaian formatif tetap dilakukan dalam porsi yang lebih singkat dan sederhana, dengan pengurangan beberapa aspek seperti pertanyaan yang hanya satu arah (guru kepada siswa) dan aplikasi pertanyaan HOTS. Ada beberapa strategi penilaian formatif dalam pembelajaran tatap muka terbatas seperti pertanyaan (questioning), diskusi, presentasi, membuat dialog sederhana, bermain peran (role play), dan picture interpretation. Aktivitas tersebut tentunya disesuaikan dengan Kompetensi Dasar yang harus dicapai siswa, disertai oleh feedback/umpan balik dan juga penguatan. Kriteria penilaian yang sesuai juga digunakan untuk menilai keterampilan tertentu. Selama proses penilaian formatif, siswa pun merasa antusias dan termotivasi, meskipun sebagian siswa masih kurang percaya diri. Oleh karena itu, dapat disimpulkan bahwa penilaian formatif sangatlah penting dilakukan, meskipun dalam kondisi yang terbatas, karena selain bisa mengetahui pencapaian siswa, motivasi mereka juga akan lebih meningkat.
\end{abstract}

Kata Kunci: penilaian formatif, motivasi, pembelajaran tatap muka terbatas

\section{ABSTRACT}

This article deals with the implementation of formative assessment in relation to students' learning motivation, especially English lessons in limited face-to-face learning conditions. The limited face-to-face learning is generally carried out in a short time so that teachers find it difficult to apply the formative assessment. Therefore, this study tries to explore the language assessment strategies carried out during the English lessons, and the extent to which students are motivated during the lessons. The research was conducted qualitatively with a case study design at a Madrasah Tsanawiyah in Ciamis, West Java. Observation and questionnaire were used to obtain data from a teacher and three students with different achievement. The data collected was analyzed qualitatively. Based on observation and questionnaire data, it can be seen that even in limited face-to-face learning conditions, formative assessment was still carried out in a shorter and simpler way, with the reduction of several aspects such as only teacher who gave questions to students and the HOTS application. There were several formative assessment strategies indicated such as questioning, discussion, presentation, making simple dialogues, role playing, and picture interpretation. These activities were of course adapted to the basic competencies that students must achieve, accompanied by feedback and reinforcement from the teacher. Appropriate criteria were also used to assess specific skills. During the formative assessment process, students felt enthusiastic and motivated, although some students still felt unconfident. To conclude, formative assessment is very necessary even in limited conditions of 
face-to-face learning, because in addition to understanding students' achievement, their motivation will also increase.

Keywords: formative assessment, motivation, limited face-to-face learning

\section{PENDAHULUAN}

Penilaian merupakan sebuah unsur penting yang tidak bisa dipisahkan dari semua proses pembelajaran. Hal ini dikarenakan penilaian bisa memberikan informasi tentang perkembangan pemahaman peserta didik terhadap materi yang telah diajarkan. Menurut Brown (2003), penilaian atau 'assessment' adalah sebuah proses yang berkelanjutan dan ekstensif. Setiap kali seorang siswa menjawab pertanyaan, membuat komentar, atau mencoba kata atau struktur baru, guru secara tidak sadar menilai siswa tersebut. Sementara itu, berdasarkan Permendikbud No. 23 Tahun 2016, penilaian adalah proses pengumpulan dan pengolahan informasi untuk mengukur pencapaian hasil belajar siswa. Itulah mengapa kita akan selalu menemukan tahap penilaian dalam sebuah kurikulum pembelajaran. Kurikulum 2013 juga termasuk salah satunya.

Sebagaimana kita tahu, kurikulum 2013 yang telah cukup lama dilaksanakan menghendaki adanya penilaian yang cenderung lebih holistik atau menyeluruh. Penilaian tidak hanya dilakukan untuk menilai pengetahuan siswa, tetapi juga untuk menilai keterampilan dan sikap mereka. Dengan penilaian yang menyeluruh, diharapkan guru bisa mendapatkan gambaran yang lengkap tentang pencapaian belajar siswa.

Penilaian itu sendiri bisa bermacam-macam tergantung karakteristiknya. Secara umum, terdapat dua jenis penilaian yang sudah kita kenal, yaitu penilaian formatif dan penilaian sumatif (tradisional). Penilaian formatif jelas berbeda dengan penilaian tradisional. Menurut Higgins, et al. (2010), penilaian formatif didefinisikan sebagai apa yang dilakukan siswa dalam proses pembelajaran untuk memperoleh umpan balik guru untuk meningkatkan prestasi belajarnya, baik tugasnya dinilai ataupun tidak. Tabel berikut ini menunjukkan perbedaan yang jelas antara penilaian formatif dan sumatif yang dikutip dari buku yang diterbitkan oleh Kemendikbud RI (2020):

Tabel 1. Perbedaan antara Penilaian Formatif dan Penilaian Sumatif

\begin{tabular}{cll}
\hline No. & \multicolumn{1}{c}{ Penilaian Formatif } & \multicolumn{1}{c}{ Penilaian Sumatif } \\
\hline 1. & $\begin{array}{l}\text { Dilakukan pada saat proses } \\
\text { pembelajaran berlangsung }\end{array}$ & Dilakukan setelah pembelajaran berakhir \\
2. & $\begin{array}{l}\text { Dilakukan untuk mengetahui } \\
\text { perkembangan siswa dalam menguasai }\end{array}$ & $\begin{array}{l}\text { Dilakukan untuk mengetahui sejauhmana } \\
\text { pencapaian belajar siswa ketika } \\
\text { materi tertentu }\end{array}$ \\
3. $\begin{array}{l}\text { Hasilnya digunakanaran telah berakhir } \\
\text { memperbaiki proses pembelajaran } \\
\text { supaya siswa lebih menguasai materi }\end{array}$ & $\begin{array}{l}\text { Hasilnya akan memberikan bukti tentang } \\
\text { apa saja yang dikuasai oleh siswa. }\end{array}$ \\
\hline
\end{tabular}

Dalam penerapannya, penilaian formatif mencakup berbagai strategi untuk mengidentifikasi pemahaman siswa, sehingga memungkinkan guru untuk mengungkap dan mengatasi kesulitan belajar mereka (Greenstein, 2010). Penilaian formatif dapat mengambil banyak bentuk, dapat tertulis atau lisan, formal atau informal, dan dapat dilakukan oleh instruktur, guru, teman, kolega, atau bahkan diri sendiri (Higgins et al., 2010). Sebagaimana yang terdapat dalam buku yang diterbitkan oleh Kemendikbud RI (2020), beberapa contoh umum penilaian formatif adalah pertanyaan, diskusi, aktivitas, konferensi, interviu, dan penilaian diri.

Dari sejak diberlakukannya kurikulum 2013 di Indonesia, tentunya guru telah berusaha semaksimal mungkin menerapkan unsur penilaian dalam pembelajaran. Namun menurut Bagus, Kusairi, dan Sutarman (2016), faktanya, penilaian formatif formal masih jarang di sekolah. Guru lebih tertarik memberikan materi untuk mencapai tujuan ujian semester atau ujian nasional. Hal ini mengindikasikan bahwa melakukan penilaian secara holistik dengan 
melakukan penilaian formatif dan sumatif tidaklah mudah, apalagi dalam situasi pandemi global covid-19, dimana siswa dan guru harus melakukan pembelajaran jarak jauh.

Ketika proses pembelajaran memasuki era 'New Normal' pasca pandemi, muncullah kebijakan moda pembelajaran yang baru juga, yaitu diberlakukannya pembelajaran tatap muka terbatas yang dimulai sejak bulan Juli tahun 2021, dengan ketentuan bahwa seluruh pendidik dan tenaga kependidikan telah melakukan vaksinasi. Proses pembelajaran pun harus dilakukan dengan cara membatasi jam pertemuan, disertai penerapan protokol kesehatan yang ketat. Hal ini tentunya memberikan angin segar bagi semua pihak karena siswa bisa kembali bersekolah, melakukan tatap muka dengan guru mereka, meskipun dalam waktu yang terbatas. Dengan lebih singkatnya waktu tatap muka, maka proses pembelajaran juga terpengaruh, diantaranya penilaian formatif yang dilakukan ketika belajar di kelas.

Dalam pembelajaran bahasa Inggris di MTs./SMP khususnya, terdapat cukup banyak Kompetensi Dasar (KD) yang harus dicapai oleh siswa, meskipun tentunya pemerintah tidak mewajibkan mereka untuk bisa memahami semua KD yang ada dalam silabus pembelajaran. Akan tetapi, guru tentunya berkeinginan supaya pembelajarannya maksimal. Hal ini jelas tidaklah mudah dan memerlukan perencanaan dan implementasi yang hati-hati tanpa mengabaikan unsur-unsur yang harus ada dalam proses pembelajaran. Kegiatan penilaian juga tentunya haruslah dilaksanakan oleh guru, baik penilaian formatif maupun penilaian sumatif.

Secara umum, kita semua tahu bahwa tujuan penilaian adalah untuk mendapatkan gambaran tentang pencapaian atau pemahaman siswa terhadap suatu materi. Popham (1995) dalam Panjaitan (2010) menyebutkan bahwa tujuan penilaian diantaranya adalah untuk melihat keberhasilan dan kelemahan siswa, dan memantau perkembangannya dalam mempelajari sebuah kompetensi. Akan tetapi, artikel ini lebih berfokus pada implementasi penilaian formatif dalam kaitannya dengan motivasi belajar siswa. Berdasarkan pengalaman penulis yang juga seorang guru, mayoritas siswa lebih merasa antusias ketika proses penilaian dilakukan di dalam kelas dengan berbagai strategi, apalagi jika mereka mendapatkan feedback/umpan balik yang positif dari guru. Hal ini sangat berbeda apabila guru hanya sebatas mengajarkan materi dengan metode lecturing/ceramah. Asumsi tersebut juga didukung oleh sebuah temuan penelitian yang menyatakan bahwa terdapat hubungan antara pemberian tes formatif dengan motivasi belajar (Utami, 2015).

Menurut Dornyei \& Ushioda (2011), motivasi adalah perubahan dinamis dalam diri individu yang berkaitan dengan harapan dan perilaku. Wu, Cheng, dan Bettney (2014) juga berasumsi bahwa siswa lebih mungkin termotivasi secara intrinsik jika metode penilaian yang digunakan guru untuk membantu siswa belajar dirasakan menyenangkan dan terasa nyata. Dengan demikian, kita bisa berasumsi bahwa penilaian yang dilakukan di dalam kelas bisa sangat mungkin meningkatkan motivasi belajar siswa.

Dalam kaitannya dengan topik artikel ini, telah banyak penelitian terdahulu yang membahas tentang penelitian formatif (formative assessment). Yang pertama adalah penelitian yang dilakukan oleh Widiastuti dan Saukah (2017) dengan judul "Formative Assessment in EFL Classroom Practices". Mereka mencoba menyelidiki tantangan dan peluang dari implementasi penilaian formatif dalam pembelajaran bahasa Inggris. Penelitian dilakukan secara kualitatif melalui wawancara mendalam kepada guru dan siswa di sebuah sekolah menengah pertama. Hasil penelitian tersebut menunjukkan bahwa guru bahasa Inggris tidak melakukan tindak lanjut yang tepat karena rendahnya pemahaman mereka tentang penilaian formatif. Artinya, pemahaman guru dapat mempengaruhi kemampuannya dalam memutuskan tindakan.

Penelitian lainnya berjudul "Pengaruh Tes Formatif dan Metode Pembelajaran Bahasa Inggris Terhadap Kemampuan Verbal Linguistik" yang dilakukan oleh Dewi (2012). Penelitian dilaksanakan di sebuah SMP Islam di Bengkulu secara kuantitatif dengan sampel sebanyak 80 siswa kelas VII yang dipilih secara klaster dan random. Hasil penelitian menunjukkan bahwa kemampuan verbal linguistik memang dipengaruhi oleh Tes Formatif dan Metode 
Pembelajaran. Selain itu, terdapat interaksi yang signifikan antara tes formatif dengan metode pembelajaran terhadap kemampuan verbal linguistik siswa.

Penelitian selanjutnya mencoba mengaitkan antara Penilaian formatif dan motivasi. Penelitian tersebut dilakukan oleh Utami (2015) dengan judul "Hubungan Tes Formatif dengan Motivasi Belajar Asuhan Persalinan Pada Mahasiswi Universitas M.H Thamrin". Penelitian ini juga dilakukan secara kuantitatif terhadap 103 mahasiswa tingkat II (Dua) di Universitas M.H.Thamrin Jakarta. Hasil penelitian menunjukkan bahwa terdapat hubungan antara pemberian tes formatif dengan motivasi belajar, dimana pemberian tes formatif dengan kategori cukup efektif dan motivasi dengan kategori tinggi. Hal ini jelas menunjukkan bahwa meskipun penilaian bertujuan untuk mendapatkan gambaran tentang pemahaman peserta didik, namun penilaian juga, khususnya penilaian formatif, bisa meningkatkan motivasi belajar siswa.

Kebanyakan penelitian terdahulu seperti halnya contoh di atas hanya berfokus pada tes formatif secara umum serta kaitannya dengan pencapaian siswa, dan semua dilakukan pada kondisi pembelajaran yang normal. Masih jarang penelitian yang mengaitkannya dengan aspek motivasi, apalagi dalam konteks pembelajaran tatap muka terbatas. Meskipun penelitian yang ketiga mencoba mengaitkannya dengan motivasi, namun penelitian tersebut dilakukan secara kuantitatif. Dengan kata lain, masih diperlukan data yang lebih mendalam untuk memperkuat temuan tersebut. Oleh sebab itu, artikel ini berfokus pada menggali data yang lebih dalam secara kualitatif dengan mengaitkan implementasi penilaian formatif dengan motivasi belajar siswa. Selain itu, penelitian ini juga dilakukan pada kondisi pembelajaran tatap muka terbatas, sehingga konteks penelitian menjadi lebih unik dan layak untuk diteliti. Secara singkat, penelitian ini bertujuan untuk mengungkap tentang: 1) bagaimana penilaian formatif diterapkan dalam pembelajaran bahasa Inggris tatap muka terbatas, dan 2) sejauh mana siswa merasa termotivasi dengan implementasi penilaian formatif tersebut.

\section{METODE PENELITIAN}

Penelitian ini menggunakan pendekatan kualitatif khususnya desain studi kasus. Hal ini dikarenakan karakteristik penelitian ini yang cenderung mengumpulkan data berupa kata-kata dan disajikan dalam bentuk narasi. Selain itu, cakupan penelitian juga spesifik, unik, dan mempunyai sedikit partisipan sehingga bisa disebut sebagai studi kasus. Penelitian ini dilakukan pada sebuah Madrasah Tsanawiyah swasta di kabupaten Ciamis, Jawa Barat, khususnya dalam konteks pembelajaran tatap muka terbatas pada semester ganjil tahun pelajaran 2021-2022. Pembelajaran tatap muka terbatas di sekolah ini mungkin sedikit berbeda dengan sekolah lain, dimana setiap tingkat hanya melakukan tatap muka di kelas sebanyak dua kali dalam seminggu, tentunya dengan alokasi waktu yang lebih sedikit. Untuk mata pelajaran bahasa Inggris, alokasi waktu menjadi hanya 2 jam pelajaran saja, dari yang biasanya 4 jam pelajaran. Selain itu, durasi pembelajaran juga hanya dilakukan selama 25 menit saja, dari yang biasanya 40 menit untuk 1 jam pelajaran. Hal ini dilakukan supaya proses pembelajaran tatap muka bisa berakhir sebelum jam 12 siang.

Seorang guru senior bahasa Inggris di kelas IX dipilih sebagai partisipan, karena guru tersebut tetap melakukan penilaian formatif dalam pembelajaran tatap muka terbatas. Sebenarnya cukup sulit mencari guru yang sering melakukan penilaian formatif dalam pembelajaran tatap muka terbatas. Dengan waktu yang terbatas, kebanyakan guru lebih berfokus pada penyampaian materi ajar, dan tentu saja penilaian formatif menjadi berkurang porsinya bahkan terlupakan. Kelas IX-A dipilih sebagai kelas untuk penelitian ini, dengan jumlah peserta didik 15 orang. Kelas tersebut merupakan kelas kecil karena diharuskan untuk saling menjaga jarak. Selain itu, tiga orang siswa dipilih sebagai partisipan berdasarkan kriteria prestasi, siswa A sebagai high achiever (tinggi), siswa B sebagai middle achiever (sedang), dan siswa $\mathrm{C}$ sebagai low achiever (rendah), dengan harapan data yang diperoleh bisa lebih kaya dan beragam.

Untuk mengumpulkan data, peneliti menggunakan dua buah instrumen untuk menjaga keabsahan dan keakuratan data, yaitu observasi non-partisipan dan angket open-ended untuk 
mendapatkan data yang lebih kaya. Observasi non-partisipan dilakukan karena peneliti tidak berpartisipasi langsung dalam aktivitas yang diamati, namun hanya duduk dan mengamati (Frankel, Wallen, \& Hyun, 2012). Observasi dilakukan pada saat pembelajaran tatap muka terbatas. Angket diberikan di tahap berikutnya kepada semua partisipan, dimana pertanyaannya juga mencakup pertanyaan follow up berdasarkan hasil observasi.

Data yang telah terkumpul lalu dianalisis secara kualitatif dengan melalui tahapan yang disarankan oleh Miles, Huberman, dan Saldana (2014), yaitu: 1) kondensasi data, 2) display data, dan 3) membuat kesimpulan dan memverifikasi. Untuk menjaga keabsahan data, dilakukan proses triangulasi dengan membandingkan data dari kedua instrumen penelitian.

\section{HASIL DAN PEMBAHASAN}

\section{Hasil}

Sebagaimana yang telah disebutkan dalam bagian Pendahuluan, salah satu tujuan penelitian ini adalah untuk mengungkap tentang bagaimana penilaian formatif diterapkan dalam pembelajaran bahasa Inggris tatap muka terbatas. Berdasarkan data dari hasil observasi, terlihat bahwa ada beberapa strategi penilaian formatif dalam pembelajaran tatap muka terbatas. Hal tersebut juga ditegaskan dalam angket yang diisi oleh guru sebagai berikut:

"Dalam melakukan penilaian formatif tatap muka terbatas, saya mencoba untuk melakukan kegiatan bertanya kepada siswa, melakukan diskusi dalam kelompok kecil, presentasi singkat, membuat dialog sederhana, bermain peran, dan membuat kalimat sederhana. Strategi yang saya lakukan tersebut disesuaikan dengan materi dan KD dalam silabus. Meskipun demikian, kegiatan penilaian formatif ini biasanya dilakukan dalam waktu singkat, karena durasi waktu yang tidak memungkinkan.”

Berdasarkan data di atas, bisa disimpulkan bahwa guru melakukan lebih dari satu strategi penilaian formatif namun dalam waktu yang lebih singkat. Strategi tersebut telah disesuaikan dengan materi dan KD yang harus dicapai dalam silabus.

Strategi pertama adalah memberikan pertanyaan (questioning). Dalam hal ini, terdapat beberapa kegiatan yang berbeda dalam pemberian pertanyaan seperti yang ditemukan dalam observasi, misalnya seperti yang terlihat dalam tabel di bawah ini:

Tabel 2. Penilaian Formatif melalui Pertanyaan

\begin{tabular}{|c|c|c|}
\hline No & Kegiatan & Contoh pertanyaan yang diberikan guru \\
\hline 1. & $\begin{array}{l}\text { Menterjemahkan arti } \\
\text { dari kosa kata tertentu }\end{array}$ & $\begin{array}{l}\text { "Please raise your hand, what is the meaning of } \\
\text { congratulations?" } \\
\text { (Coba acungkan tangan, apa arti dari congratulations?) }\end{array}$ \\
\hline 2. & $\begin{array}{l}\text { Menonton } \\
\text { singkat } \\
\text { demonstrasi } \\
\text { prosedur }\end{array}$ & $\begin{array}{l}\text { "After watching the video, we know that they are making } \\
\text { fried rice. How many steps are there to make fried rice?" } \\
\text { (Setelah menonton video, kita tahu bahwa mereka sedang } \\
\text { membuat nasi goreng. Berapa jumlah tahapan untuk } \\
\text { membuat nasi goreng?") }\end{array}$ \\
\hline 3. & $\begin{array}{ll}\text { Membaca } & \text { dan } \\
\text { membandingkan } & \text { teks } \\
\text { singkat } & \end{array}$ & $\begin{array}{l}\text { "Look at the labels: Label A and Label B! Which one do you } \\
\text { think is a medicine label?" } \\
\text { (Coba lihat label ini: Label A dan Label B! Yang mana } \\
\text { menurutmu yang merupakan label obat?) }\end{array}$ \\
\hline
\end{tabular}

Selain contoh pertanyaan di atas, banyak lagi jenis pertanyaan yang diberikan oleh guru. Akan tetapi, sangat jarang ditemukan pertanyaan HOTS dalam pembelajaran tersebut. Selain itu, pertanyaan juga cenderung hanya dilakukan satu arah saja, yaitu guru kepada siswa. Dalam angketnya guru tersebut beralasan bahwa:

"Untuk strategi pertanyaan, saya cenderung dominan bertanya kepada siswa, karena kebanyakan siswa memang enggan untuk bertanya. Mungkin nanti ketika pembelajaran sudah normal lagi, saya juga berfokus merangsang siswa untuk bertanya. Pertanyaan 
HOTS untuk sementara saya kurangi dulu, karena waktu yang terbatas untuk siswa berfikir, dan jenis soal itu akan merupakan penugasan nanti ketika belajar di rumah dengan waktu yang lebih leluasa."

Untuk jenis penilaian ini, guru memberikan nilai individu sesuai dengan jawaban yang diberikan oleh peserta didik. Selain itu, terdapat juga feedback lisan berupa pujian maupun penguatan yang diberikan oleh guru terhadap jawaban siswa. Berikut adalah contoh yang ditemukan dalam observasi:

Guru : Please raise your hand, what is the meaning of congratulations?

Siswa 1 : Selamat, sir!

Guru : That's right.

Strategi yang kedua adalah diskusi kelompok. Diskusi kelompok dilakukan diantaranya ketika pembelajaran melengkapi sebuah tabel kosong dengan data tentang label obat dan makanan. Selain itu, diskusi kelompok juga dilakukan ketika siswa disuruh membaca teks dengan kosa kata yang tidak terlalu mudah, misalnya teks tentang manual. Berdasarkan data dari angket, guru menggarisbawahi bahwa aspek yang dinilai dari diskusi tidak hanya hasil akhirnya saja, melainkan proses yang terjadi ketika anggota kelompok saling bertukar pikiran. Diskusi juga tidak sering dilakukan di kelas karena pertimbangan waktu yang terbatas. Diskusi hanya dilakukan untuk materi yang memang tidak mudah untuk dikerjakan secara individual. Selama proses diskusi berlangsung, guru sekali-kali berkeliling memeriksa setiap kelompok apabila ada kesulitan dalam mengerjakan tugas. Selama observasi, penulis juga melihat bahwa guru memberikan beberapa feedback positif untuk tugas yang dikerjakan dengan benar, seperti dalam dialog berikut ini:

Guru : So, do you have any problems with the label?

Siswa 2 : Yes, sir! Disini tidak ada expiry date-nya.

Guru $\quad$ : Let me see. Oh, this one! Nah ini yang tulisan 'best before' juga mempunyai arti yang sama, yaitu tentang masa kadaluarsa.

Siswa 2 : I see. Thanks, Sir.

Guru : My pleasure.

Strategi selanjutnya adalah presentasi. Presentasi dilakukan secara singkat dan sederhana untuk menampilkan hasil diskusi kelompok. Misalnya mempresentasikan hasil diskusi terkait fakta-fakta label obat/makanan. Akan tetapi, kegiatan presentasi ini hanya dilakukan satu kali karena membutuhkan waktu yang relatif lama, khususnya bagi siswa untuk melakukan persiapan. Penilaian dilakukan dengan menerapkan beberapa aspek seperti pronunciation (pelafalan) dan fluency (kepasihan), tentunya disertai dengan masukan dan saran (corrective feedback) dari guru.

Strategi penilaian formatif keempat yang dilakukan adalah membuat dialog sederhana. Sebagai contoh, siswa disuruh membuat dialog tentang mengucapkan selamat (congratulating), dan mengungkapkan harapan dan do'a (expressing hope and wish). Ketika sudah selesai, maka guru menilai tulisan anak berdasarkan aspek:

1. Content (isi): apakah isi dialog memang sesuai dengan tema

2. Organization: apakah dialog tersebut ditulis dengan struktur/urutan yang benar

3. Vocabulary: apakah kosa kata yang digunakan sesuai dengan tema dan konteks dialog

4. Language use (grammar): apakah kalimat dalam dialog tersebut sesuai dengan tata aturan bahasa Inggris

5. Mechanics: apakah dialog ditulis dengan tanda baca, kapitalisasi, dan ejaan yang benar

Selain memberikan nilai, guru juga memberikan corrective feedback apabila ada kesalahan dalam penulisan dialog tersebut.

Strategi penilaian formatif kelima adalah bermain peran (role play) yang menilai kemampuan keterampilan berbicara siswa. Strategi ini merupakan lanjutan dari strategi sebelumnya yaitu membuat dialog. Dialog yang telah diperiksa dan diberi masukan, harus 
direvisi dan ditampilkan oleh dua orang siswa. Dialog ditampilkan di bangku masing-masing. Alasan guru melakukan hal tersebut adalah karena waktu yang terbatas. Maka supaya cepat, dialog cukup dilakukan di tempat duduk saja. Penilaian dialog dilakukan dengan menerapkan beberapa aspek seperti pronunciation (pelafalan) dan fluency (kepasihan). Aspek lain seperti kosa kata dan tata bahasa tidak masuk penilaian karena sudah dinilai ketika pembuatan dialog tersebut.

Strategi yang terakhir adalah membuat kalimat sederhana dengan menggunakan ilustrasi/gambar sebagai petunjuk atau 'picture interpretation'. Strategi ini tampak dalam pembelajaran dengan topik tata bahasa, khususnya Present Continuous Tense. Setelah guru menjelaskan tentang fungsi dan pola kalimat Present Continuous, lalu guru menunjukkan beberapa buah gambar aktivitas tertentu yang cenderung sederhana dan bisa dengan mudah dipahami siswa. Misalnya, guru menunjukkan gambar seorang anak laki-laki yang sedang membaca buku, maka siswa harus membuat kalimat sederhana dengan pola Present Continuous yang menggambarkan kegiatan dalam gambar tersebut, seperti yang terlihat di bawah ini:

Tabel 3. Penilaian Formatif Membuat Kalimat Sederhana

\begin{tabular}{ll}
\hline No & \multicolumn{1}{c}{ Contoh jawaban siswa } \\
\hline 1. & $\begin{array}{l}\text { The boy is reading a book. } \\
\text { (Anak laki-laki itu sedang membaca sebuah } \\
\text { buku.) }\end{array}$
\end{tabular}

Sebagai tambahan, guru juga menekankan bahwa setiap pekerjaan anak yang disetorkan akan diberikan nilai dan juga tanda tangan sebagai apresiasi dari apa yang telah mereka kerjakan. Di akhir semester, skor dan tanda tangan tersebut akan dihitung dan dimasukkan ke dalam daftar nilai.

Tujuan penelitian yang kedua adalah untuk menggali sejauh mana siswa merasa termotivasi dengan implementasi penilaian formatif tersebut. Terkait tujuan ini, data dari observasi menunjukkan bahwa peserta didik cenderung antusias dalam mengerjakan tugastugas penilaian formatif, meskipun banyak diantaranya yang masih belum dipahami dan mendapatkan feedback/masukan dari guru. Data dari angket juga menunjukkan hal yang senada. Dua buah pertanyaan inti diberikan kepada partisipan siswa sebagai berikut:

1) Apakah Anda merasa lebih semangat/termotivasi dengan penilaian yang dilakukan selama pembelajaran di kelas? Jelaskan alasan Anda!

2) Proses pembelajaran mana yang lebih Anda sukai: guru hanya menjelaskan materi, atau guru menjelaskan materi disertai dengan kegiatan penilaian selama pembelajaran? Jelaskan alasan Anda!

Jawaban partisipan tampak dalam tabel di bawah ini:

Tabel 4. Motivasi dan Preferensi Siswa dalam Kegiatan Penilaian Formatif

\begin{tabular}{|c|c|c|}
\hline No & Nama & Jawaban angket \\
\hline 1. & $\begin{array}{l}\text { Siswa A } \\
\text { (high } \\
\text { achiever) }\end{array}$ & $\begin{array}{l}\text { 1) Iya, saya merasa termotivasi, karena menurut saya pemberian } \\
\text { penilaian pembelajaran itu sangat dibutuhkan, untuk mengetahui } \\
\text { seberapa besar kemampuan pengetahuan kita dalam pembelajaran }\end{array}$ \\
\hline
\end{tabular}


di kelas, dan disamping itu juga akan menjadi motivasi/dorongan agar kita bisa lebih dan lebih lagi dalam belajar.

2) Menurut saya lebih baik guru menjelaskan materi disertai dengan kegiatan penilaian, karena dengan mengadakan latihan kegiatan penilaian, maka akan lebih memperdalam lagi pengetahuan dalam materi tersebut, dan juga kita akan mengetahui seberapa besar kemampuan pengetahuan kita dalam materi tersebut yang telah disampaikan.

2. Siswa B

(middle

achiever)

3. Siswa C

(low

achiever)
1) Ya, karena saya bisa secara langsung berkomunikasi dengan guru menanyakan apa yang saya tidak mengerti dan suasana dengan adanya teman-teman di sekitar membuat saya menjadi lebih semangat.

2) Proses pembelajaran yang saya suka adalah guru menjelaskan materi disertai dengan kegiatan penilaian selama pembelajaran, karena lebih mengasah otak, melatih kedisiplinan, dan juga kemampuan.

1) Iya, sebetulnya saya semangat, namun seringkali merasa tidak percaya diri karena saya tidak bisa dan kurang paham mata pelajaran bahasa Inggris.

2) Guru menerangkan materi disertai dengan kegiatan penilaian selama pembelajaran, karena dengan cara proses itu, kita dapat mengerti materi yang guru berikan dan juga kita mendapatkan nilai selama pembelajaran.

Berdasarkan data diatas, secara singkat bisa dikatakan bahwa siswa merasa antusias dan termotivasi dengan penilaian formatif yang dilakukan oleh guru, terutama bagi siswa yang tergolong high dan middle achiever. Bahkan partisipan low achiever pun merasa semangat, meskipun dia merasa terbebani karena tidak percaya diri dan kurangnya pemahaman dalam mata pelajaran bahasa Inggris. Mereka juga cenderung lebih memilih pembelajaran dengan penilaian formatif di dalamnya, karena akan lebih memperdalam lagi pengetahuan, akan mengetahui seberapa besar kemampuan pengetahuannya, lebih mengasah otak, serta melatih kedisiplinan dan kemampuan.

\section{Pembahasan}

Berdasarkan hasil atau temuan dari kedua instrumen, guru menerapkan berbagai strategi penilaian formatif di dalam kelas, meskipun dalam porsi yang singkat dan sederhana. Strategi penilaian formatif yang diterapkan guru seperti pertanyaan (questioning), diskusi, pengamatan penggunaan bahasa siswa dalam berbicara dan menulis, picture interpretation, dan aktivitas lain juga tercantum dalam buku Kemendikbud (2020) tentang penilaian formatif untuk SMP/MTs dan juga sesuai dengan pernyataan Montalvo-Balbed (2012).

Dalam strategi questioning, perlu dicatat juga bahwa guru cenderung melakukan strategi ini satu arah saja, yaitu guru yang bertanya untuk menguji pemahaman anak. Pertimbangannya adalah karena kebanyakan siswa memang enggan untuk bertanya. Namun ketika pembelajaran sudah normal lagi, guru tersebut akan berfokus juga merangsang siswa untuk bertanya. Hal ini sejalan dengan temuan penelitian Cahyani, Nurjaya, \& Sriasih (2015) bahwa penyebab siswa jarang bertanya kepada guru saat pembelajaran adalah rasa malu, gugup, dan tidak percaya diri. Selain itu, jarang juga ditemukan pertanyaan HOTS dalam penilaian formatif tersebut, dengan alasan karena waktu yang terbatas untuk siswa berfikir. Seperti yang dikatakan oleh Intan, Kuntarto, dan Alirmansyah (2020), soal-soal HOTS (Higher Order Thinking Skills) merupakan suatu instrumen yang menilai kemampuan berpikir tingkat tinggi siswa, dimana mereka tidak sekedar mengingat atau menyatakan kembali namun mampu mengembangkan ide dan 
gagasannya. Meskipun demikian, jenis pertanyaan HOTS tersebut dijadikan penugasan oleh guru untuk dikerjakan di rumah dengan waktu yang lebih leluasa.

Feedback atau umpan balik juga diberikan oleh guru, terutama dalam kegiatan keterampilan menulis dan berbicara. Hal ini juga sejalan dengan yang dikemukakan oleh Regier (2012) bahwa umpan balik deskriptif biasanya disertakan bersama dengan penilaian formatif untuk memberi tahu siswa jika materi tertentu telah dikuasai atau jika diperlukan lebih banyak latihan. Greenstein (2010) juga menekankan bahwa salah satu manfaat penilaian formatif adalah bisa memberikan umpan balik yang dapat dipahami, dapat ditindaklanjuti, dan juga relevan.

Selain itu, untuk menilai hasil pencapaian siswa, misalnya dalam keterampilan menulis dan berbicara, tampak bahwa guru menerapkan kriteria penilaian yang tepat dan sesuai teori. Sebagai contoh, untuk menilai tulisan anak, guru menggunakan lima kriteria penilaian menurut ESL Composition Profile (Jacobs, et al., 1981) yang dikutip juga dalam Zinkgraf (2014). Untuk penilaian berbicara, guru juga menggunakan kriteria menurut Brown (2003).

Temuan lain menunjukkan bahwa respon siswa juga terlihat positif karena mereka cenderung lebih bersemangat apabila guru tidak sekedar mengajar, tetapi juga memberikan penilaian. Dalam kaitannya dengah hasil penelitian terdahulu, penelitian ini memperkaya temuan Dewi (2012) bahwa kemampuan verbal linguistik memang dipengaruhi oleh tes formatif dan metode pembelajaran. Dengan kata lain, penilaian formatif tidak hanya bisa meningkatkan kemampuan verbal linguistik, tetapi juga bisa meningkatkan motivasi siswa. Temuan ini juga mendukung pernyataan Greenstein (2010) bahwa penilaian formatif bisa meningkatkan keterlibatan dan motivasi siswa.

Lebih jauh lagi, hasil penelitian ini juga melengkapi hasil penelitian terdahulu oleh Utami (2015) yang mengkaji hubungan antara penilaian formatif dan motivasi dan dilakukan secara kuantitatif. Penelitian tersebut menyimpulkan bahwa terdapat hubungan antara pemberian tes formatif dengan motivasi belajar, dimana pemberian tes formatif dengan kategori cukup efektif dan motivasi dengan kategori tinggi. Dengan kata lain, penilaian formatif bisa meningkatkan motivasi belajar siswa. Secara kualitatif, ternyata siswa juga memberikan respon yang positif terhadap implementasi penilaian formatif, seperti bisa dilihat dalam poin sebelumnya.

Di luar semua temuan penelitian ini yang cenderung positif, perlu juga dicatat bahwa terdapat juga temuan penting yang mungkin terkadang tidak disadari oleh guru. Hal ini menyangkut rasa tidak percaya diri dan minder yang dialami oleh siswa low achiever, terutama ketika penilaian formatif harus dikerjakan oleh masing-masing individu.

\section{KESIMPULAN}

Berdasarkan hasil dan pembahasan, dapat disimpulkan bahwa dalam kondisi pembelajaran tatap muka terbatas sekalipun, penilaian formatif juga tetap bisa dilakukan meskipun dalam porsi yang lebih singkat dan sederhana, dengan pengurangan beberapa aspek seperti pertanyaan yang hanya satu arah (guru kepada siswa), dan juga aplikasi pertanyaan HOTS. Dalam penelitian ini, tampak bahwa berbagai strategi digunakan oleh guru untuk menilai pencapaian siswa, disertai oleh feedback/umpan balik dan juga penguatan. Selama proses penilaian formatif, siswa pun merasa antusias dan termotivasi, meskipun sebagian siswa masih kurang percaya diri. Dengan kata lain, penilaian formatif sangatlah penting dilakukan, karena selain bisa mengetahui pencapaian siswa, motivasi mereka juga akan lebih meningkat.

Hasil penelitian ini tentunya masih mempunyai beberapa kekurangan, karena hanya berfokus pada strategi penilaian formatif dan motivasi siswa semata. Oleh sebab itu, penelitian selanjutnya bisa berfokus pada aspek lainnya, misalnya menggali feedback/umpan balik yang dilakukan dalam penilaian formatif, atau mungkin bisa hanya berfokus pada salah satu strategi penilaian formatif saja. Selain itu, masih juga diperlukan penelitian lanjutan untuk menggali lebih dalam tentang perilaku siswa low achiever dalam proses penilaian formatif. 
DAFTAR PUSTAKA

Bagus, B., Kusairi, S., \& Sutarman. (2016). Pengembangan model penilaian formatif formal berbantuan komputer untuk membantu pembelajaran dinamika rotasi. Jurnal Tarbiyah (Jurnal Ilmiah Kependidikan), 5(2), 7-22, from https://jurnal.uinantasari.ac.id/index.php/jtjik/article/download/981/781.

Brown, H. D. (2003). Language assessment: Principles and classroom practices. San Francisco, CA: Longman.

Cahyani, P. A. H. I., Nurjaya, I. G., \& Sriasih, S. A. P. (2015). Analisis keterampilan bertanya guru dan siswa dalam pembelajaran bahasa indonesia di kelas X TAV 1 SMKN 3 Singaraja. E-Journal Universitas Pendidikan Ganesha, 3(1), 1-12, from http://dx.doi.org/10.23887/jipbs.v3i1.7204

Dewi, C. (2012). The effects of formative test and English instructional method on the students' verbal linguistic competence. Jurnal Penelitian dan Evaluasi Pendidikan, 16(1), 209233, from https://doi.org/10.21831/pep.v16i1.1114.

Dornyei, Z., \& Ushioda, E. (2011). Teaching and researching motivation (2nd Ed.). Harlo, UK: Pearson Education Ltd.

Frankel, J. R., Wallen, N. E., \& Hyun, H. H. (2012). How to design and evaluate research in education (8th Ed.). New York, NY: McGraw-Hill.

Greenstein, L. (2010). What teachers really need to know about formative assessment. Alexandria, VA: ASCD Publications.

Higgins, M., Grant, F., Thompson, P., dan Montarzino, A. (2010). Effective and efficient methods of formative assessment. CEBE Innovative Project in Learning \& Teaching.

Intan, F. M., Kuntarto, E., \& Alirmansyah. (2020). Kemampuan siswa dalam mengerjakan soal HOTS (Higher Order Thinking Skills) pada pembelajaran matematika di kelas V sekolah dasar. Jurnal Pendidikan Dasar Indonesia, 5(1), 6-10, from http://dx.doi.org/10.26737/jpdi.v5i1.1666

Kemendikbud RI. (2020). Penilaian berbasis kelas/teknik-teknik penilaian formatif untuk sekolah menengah pertama, from http://ditsmp.kemdikbud.go.id/penilaian-berbasiskelas-teknik-penilaian-formatif/

Miles, M. B., Huberman, A. M., \& Saldana, J. (2014). Qualitative data analysis: A methods sourcebook. Thousand Oaks, CA: SAGE Publications.

Montalvo-Balbed, M. (2012). Using formative assessment to help English language learners, from

https://pdo.ascd.org/lmscourses/PD13OC002/media/ELL_CC_M4_Reading_Using_ Formative01.pdf.

Panjaitan, M. O. (2010). Penilaian mata pelajaran bahasa Inggris. Jurnal Pendidikan dan Kebudayaan, 16(3), 311-324, from https://jurnaldikbud.kemdikbud.go.id/index.php/jpnk/article/download/464/310/.

Permendikbud RI No. 23 Tahun 2016, Standar Penilaian Pendidikan.

Regier, N. (2012). Book two: 60 formative assessment strategies. Regier Educational Resources, from https://portal.gssd.ca/public/mr3xg4k4nrxxq5dvfz4hq5lomq/Lists/SharedDocuments/ Assessment/Formative\%20Assessment\%20Ideas-Natalie\%20Regier.pdf.

Utami, F. P. (2015). Hubungan tes formatif dengan motivasi belajar asuhan persalinan pada mahasiswi universitas M.H. Thamrin. Jurnal Ilmu Kesehatan, 7(2), 119-125, from http://lp3m.thamrin.ac.id/upload/jurnal/JURNAL-1519701905.pdf.

Widiastuti, I. A. M. S., \& Saukah, A. (2017). Formative assessment in EFL classroom practices. Jurnal Bahasa Sastra Seni dan Pengajarannya, 45(1), from dx.doi.org/10.17977/um015v45i12017p050.

Wu, Y., Cheng, L., \& Bettney, E. (2014, Juni). Assessment and motivation: Perspectives from teacher candidates. Artikel dipresentasikan pada Conference International Council on Education for Teaching World Assembly, Oshawa, Ontario, Canada. From 
https://www.researchgate.net/publication/296060341_Assessment_and_Motivation_ Perspectives_from_Teacher_Candidates.

Zinkgraf, S. A. (2014). Testing ESL composition: A Practical Approach, from https://www.researchgate.net/publication/247716030 